\title{
Allelopathic Effects of Cereal Rye on Weed Suppression and Forage Yield in Alfalfa
}

\author{
Laxman Adhikari, Mohsen Mohseni-Moghadam, Ali Missaoui* $^{*}$ \\ Institute of Plant Breeding, Genetics and Genomics, University of Georgia, Athens, GA, USA \\ Email: *cssamm@uga.edu
}

How to cite this paper: Adhikari, L., Mohseni-Moghadam, M. and Missaoui, A. (2018) Allelopathic Effects of Cereal Rye on Weed Suppression and Forage Yield in Alfalfa. American Journal of Plant Sciences, 9, 685-700.

https://doi.org/10.4236/ajps.2018.94054

Received: January 12, 2018

Accepted: March 11, 2018

Published: March 14, 2018

Copyright () 2018 by authors and Scientific Research Publishing Inc. This work is licensed under the Creative Commons Attribution International License (CC BY 4.0).

http://creativecommons.org/licenses/by/4.0/

\begin{abstract}
Cereal rye (Secale cereale L.) is widely used as cover crop because of its allelopathic effects and effectiveness in weed suppression. In the Southeastern US, rye is traditionally grown for winter grazing in dormant bermudagrass pastures, where alfalfa (Medicago sativa L.) is increasingly planted as a companion crop. The effect of cereal rye on alfalfa as a succeeding crop is not known. Therefore, the objective of this study was to evaluate the effect of cereal rye on alfalfa seedling emergence, growth, forage yield, and weed suppression in field conditions. Rye was planted in the fall (mid-October) and the biomass was harvested in spring (March) followed by disking and incorporation of the remaining stubble in the soil. Alfalfa seed was planted four weeks later. The experiment design was a split-plot design with the main plots being no-rye and after-rye and the sub-plots being alfalfa cultivars. Ten alfalfa cultivars were planted in three replications after-rye and three replications with no-rye as a previous crop. In the establishment year, weed density was significantly $(\mathrm{p}<0.01)$ lower in the after-rye alfalfa plots by nearly $77 \%$. Alfalfa seedling counts were also significantly lower $(p<0.01)$ among the cultivars planted in the after-rye block compared to the no-rye, with a seedling count reduction between $35 \%$ and $64 \%$. Reduction in total dry biomass yield varied from $15 \%$ to $43 \%$ among the cultivars planted in the after-rye block. The results of this study also suggest that the allelopathic effect of rye on alfalfa may not persist beyond the establishment season, but the enormous yield reduction in the first production season may constitute a costly economic penalty in terms of forage production. There was variation in the response of different alfalfa cultivars to the effect of rye residue as indicated by the variation in the magnitude of reduction in stand count and forage yield. This warrants more research in multi-location trials with and without rye in order to establish whether there is genetic variation in alfalfa germplasm in their tolerance to cereal rye allelopathy.
\end{abstract}




\section{Keywords}

Allelopathy, Alfalfa, Cereal Rye, Biological Weed Control, Biomass

\section{Introduction}

Alfalfa (Medicago sativa L.) is a perennial, cool season, C3 forage species cultivated throughout the world and is primarily used for hay, pasture, silage, and cover crop [1]. Alfalfa and its mixtures make most of the hay production in the US, with nearly 7 Million ha planted in 2017 [2]. Alfalfa makes cropping system sustainable by reducing soil erosion, enhancing soil quality, and fixes atmospheric nitrogen in the soil [3]. As a perennial crop, alfalfa persists for multiple years, reducing the cost of establishment. Several biotic and abiotic factors pose challenges to alfalfa seed germination, emergence and seedling growth in the establishment phase. Weeds compete with alfalfa for light, water, and nutrients [4] [5] and consequently reduce yield and forage quality [6]. Newly established stands are especially more vulnerable [7], but older stands [8] and frequently cut stands [9] [10] are also affected. Therefore, the first year of planting is very crucial in terms of crop establishment, biomass yield, and stand persistence of alfalfa.

In the Southeastern US, alfalfa is increasingly grown as a companion crop in bermudagrass pastures. It offers producers a significant profit potential through selling hay, or by grazing or conserving the surplus as haylage. Most of these growers were attracted to alfalfa because they have seen enormous improvement in the quality of their hay, and they were able to save on the application of nitrogen fertilizer. Studies evaluating the sustainability of production of alfalfa interseeded in bermudagrass showed that alfalfa competes well with bermudagrass, even in drought conditions [11]. Another part of the forage system in the region is cereal rye that is grown for late fall and early winter grazing when bermudagrass goes dormant. There is no information available of the reaction of alfalfa if planted following cereal rye. The allelopathic effect of rye has been recognized since the early 1980's, and a number of studies have illustrated the extent and severity of rye allelopathy over other species [12]. Rye reduced the density and biomass of weed species such as redroot pigweed and common lambsquarters, when used as cover crop mulch in soybean, and enhanced soybean yield [13]. Utilization of winter rye cover crop reduced corn biomass yield by $10 \%$ to $15 \%$ and the effect was more severe under no-till system [14]. The role of cereal rye (Secale cereal L.) to suppress weeds was described extensively [15] [16]. To control weeds in other crops, rye can be utilized as cover or mulch. However, to control weeds, highly allelopathic rye cultivars are required [17]. The influence of rye residue on germination of different plant species such as lettuce (Lactuca sativa L. "Ithaca"), proso millet (Panicum miliaceum L.) [18], and corn was described [17] [19]. Barnes and Putnam (1987) reported the effect of two phytotoxic 
compounds from rye: [2,4-dihydroxy-1,4(2H)-benzoxazin-3-one (DIBOA) and $2(3 \mathrm{H})$-benzoxazolinone $(\mathrm{BOA})]$ on germination of various dicots and monocots such as, lettuce (Lactuca sativa L.), tomato (Lycopersicon esculentum Mill.), barnyardgrass (Echinochloa crusgalli L. Beauv.), cress (Lepidium sativum L.) etc. [16]. Another phytotoxic compound extracted from rye is hydroxamic acid $(\mathrm{Hx})$, which is exuded from plant roots and can reduce weed biomass by up to $80 \%$ compared to other cover crops [20]. Further, the Hx released from rye also inhibits the growth of other species such as Avena fatua [21].

The term "allelopathy" refers mostly to detrimental interactions between plant species, and is triggered by allelochemicals produced by one of the plants [22]. In addition to producing allelochemicals, allelopathic crops and their residues also produce microbial toxins at the time of decomposition, which jointly create a phytotoxic environment [23]. Allelochemicals are released from plant roots, leaves, and stems [24] and affect other crops within the same area [25]. Allelopathy has been exploited for controlling weeds either by growing allelopathic crops prior to planting main crops or by isolating and applying the active natural compounds from the allelopathic crop as natural herbicides [26] [27]. Crops such as rice (Oryza sativa L.), wheat (Triticum aestivum L.), barley (Hordeum vulgare L.), oat (Avena spp.), cereal rye (Secale cereale L.), soybean (Glycine max) etc. have been recognized for their allelopathic activities [27]. Similarly, allelopathy of some legumes such as black gram (Vigna mungo) [28], mung bean (Vigna radiate) etc. have also been reported [29]. Allelopathy has been used to manage weeds and is considered as natural herbicides that are safer to the environment compared to synthetic herbicides [30]. For instance, phytotoxic products from sorghum (Sorghum bicolor L.) and Sudangrass (Sorghum sudanense) hybrids were effective in suppressing alfalfa, Johnsongrass, annual ryegrass ( $L o$ lium multiflorum L.), common lambsquarters and large crabgrass [31]. Similarly, rice hull incorporated alfalfa-rice-byproducts were reported as very effective allelopathic materials to inhibit weed emergence in paddy fields [32]. Alfalfa pellets were effective in suppressing the emergence of Eleocharis acicularis and Rotalaindica when applied at the dose of three tons $\mathrm{ha}^{-1}$ [33]. Additionally, alfalfa decomposed roots acted as allelopathic agents on bladygrass (Imperata cylindrica) and reduced seed germination by $50 \%$ [34]. Alfalfa is also recognized for its own autotoxicity and researchers have recommended not planting alfalfa seed in an established alfalfa stand [33].

In recent years, scientists have acknowledged allelopathy as a biotechnological tool to manage weeds targeting either the transfer of allelopathic genes from donor plants to the crop of interest through breeding or genetic engineering, or by enhancing the crop itself to produce phytotoxins via cell cultures [22]. In rice, scientists have explored the variability in allelopathy among different cultivars and identified quantitative trait loci (QTL) associated with rice allelopathy [35]. Rice cultivars with increased allelopathy have also been identified [36]. In other crops such as wheat, QTLs underlying allelopathy and molecular markers were 
also identified [37]. Moreover, sorghum cultivars that differ in their ability to produce allelochemicals were reported, where some cultivars showed higher allelopathic effects with potential to use for trait improvement [38]. Other reports discussing the genetic mechanisms and the genetic diversity involved in allelopathy are available. Horton et al. (2005) reported that variability is present in different rye cultivars with respect to their content of allelochemicals [39]. Variability in rye cultivars for $\mathrm{BOA}$, benzoxazinoid, and other allelochemicals was reported [17] [40] [41]. Brooks et al. (2011) reported that the production of the allelochimical benzoxazinoid in rye is a heritable trait [42]. Similarly, Xuan and Tsuzuki (2002), reported differences among alfalfa varieties in their allelopathic potential and suggested that allelopathy could be controlled by several genes [22]. Furthermore, two alfalfa varieties, Rasen and Yuba, were selected among eight cultivars for their higher allelopathy potential to suppress weeds such as lettuce (Lactuca sativa L.) baryardgrass (Echinocholoa oryzicola), and monochoria (Monochoria vaginalis) in rice fields [32].

In this study, we evaluated the allelopathic effect of rye residues grown as a winter crop on subsequently planted alfalfa cultivars. Cereal rye is a major winter grazing crop in livestock production systems in the southeastern US. Because of its cold-tolerance compared to other small grains. Rye provides the most fall grazing, but matures earlier, allowing for crops such as alfalfa to be planted successively in spring. The responses of alfalfa to the allelopathic effects of rye have not been documented. Therefore, the objectives of this study were, 1) to assess the effects of rye on alfalfa seed germination, seedling growth, weed invasion, and forage yield, 2) to evaluate the performance of different alfalfa cultivars in their response to rye allelopathy.

\section{Materials and Methods}

\subsection{Plant Material and Experimental Design}

The experiment was conducted at the J. Phil Campbell Sr. Research and Educa-

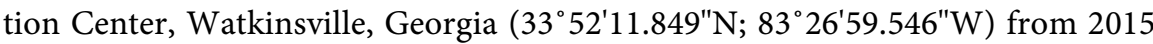
to 2017. The soil was a Cecil sandy loam, Fine, kaolinitic, thermic Typic Kanhapludults with $\mathrm{pH} 6.6$ and organic matter content of $1 \%$. The average annual precipitation is $48 \mathrm{inch}$. The average annual high temperature is $72.2^{\circ} \mathrm{F}$ and the average annual low temperature is $50.3^{\circ} \mathrm{F}$ [43]. Ten alfalfa commercial cultivars BD505, Ameristand 403T (AS 403T), GrandSlam, WL363 HQ CO, WL535, Aquamate, Phoenix, Arapaho II, Evermore, and Ameristand 407 TQ (AS 407TQ), were tested under two growing conditions (treatments). The first experimental group was a no-rye or control, where rye was not previously planted in the block. The second group was treatment or after-rye, where rye was planted previously as a cover crop. Each plot was $4.6 \times 1.5 \mathrm{~m}^{2}$ in size with a spacing of 19 $\mathrm{cm}$ between the rows. The spacing between adjacent plots was $0.5 \mathrm{~m}$, and $1.5 \mathrm{~m}$ wide alleys separated the blocks (Figure 1). The experimental design was split-plot in randomized block with three replications, where the main factor 


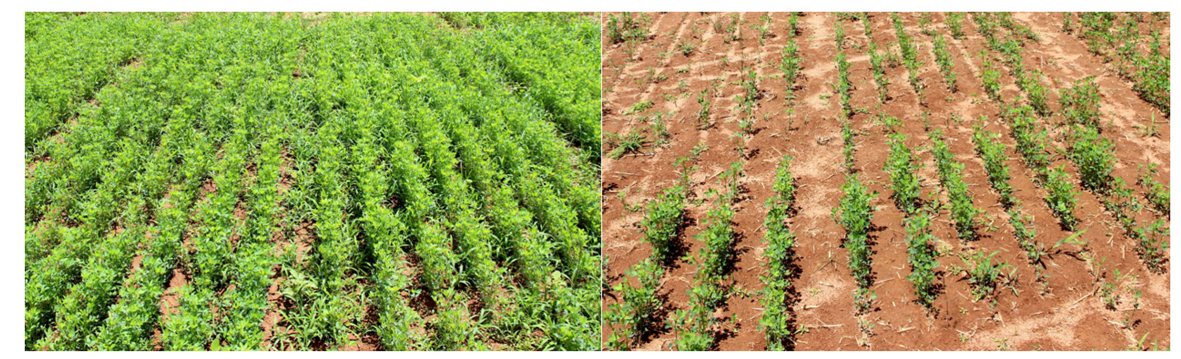

Figure 1. Image of alfalfa plots six week after planting in April 2015 in Watkinsville, GA. Plots on the left show different alfalfa cultivar planted in an area that has no-rye as a previous crop. The plots on the right show the same cultivars planted following rye (After-rye). Establishment in the after-rye plots was poor even though there was a minimal presence of weeds in the plots.

"treatment" had two levels, after-rye and no-rye, and the sub-plots were the alfalfa cultivars with 10 levels.

In the after-rye block, cereal rye was planted as a winter cover crop on 12 October 2014 and the biomass was harvested on 24 March 2015. The residual stubble was thoroughly incorporated in the soil by disking. The "no-rye" control block was fallow. Alfalfa seed was row planted on 28 April 2015 using a kincaid/great plains 3P606NT 6' drill (kincaid equipment MFG, Haven, KS). Fertilizer was applied based on soil testing. In the second year after planting, $282 \mathrm{lbs} \mathrm{K}$ $\mathrm{acre}^{-1}$ of 006 (NPK) were applied using an Earthway push spreader. The herbicides (Pursuit 4 oz/acre, Volunteer/Clethodim 1 pt/acre, Prowl $\mathrm{H}_{2} \mathrm{O} 1.5$ qt/acre, drift retardant and Crop Oil $1 \% \mathrm{v} / \mathrm{v}$ ) were also applied in the second year.

Plant height and the number of seedlings per square foot were measured on the 3 June 2015 and weed ground cover was visually estimated on 4 June 2015. Weed species present in each block were identified and recorded (Table 3). Alfalfa forage biomass was harvested using a Swift flail harvester (swift machine \& welding Ltd. SK, Canada). In 2015, the plots were harvested on 1 July, $17 \mathrm{Au}$ gust, and 22 September. Similarly, in 2016, alfalfa biomass was harvested on $27^{\text {th }}$ of April, $27^{\text {th }}$ of June, $27^{\text {th }}$ of July and $29^{\text {th }}$ of August. Total dry biomass yield per plot per year was estimated in $\mathrm{kg} \cdot \mathrm{ha}^{-1}$ by adding the forage yield for the cuts taken in the particular year.

To explore the long term effect of rye on the alfalfa cultivars, forage yield was measured in the third season after establishment (2017). The plots were harvested four times on 11 May 2017, 16 June 2017, 13 July 2017, and 24 August 2017. Total dry biomass yield was calculated and compared between the rye treatments and between the cultivars within each treatment.

\subsection{Data Analysis}

Data analysis was performed using SAS 9.4 (๑ SAS Institute Inc.) and JMP (JPM 13.0) software. The means and variances of variables under consideration were estimated using PROC GLM $(\alpha=0.05)$ procedure in SAS. Pairwise comparisons between variable means of 10 genotypes were conducted using Tukey's post-hoc 
test, where the overall group means were statistically significant [44]. Pairwise comparisons were made for the means of seedling count (SC), height, and total dry weight (DWT) (Figure 2, Table 1 and Table 2). In order to assess the magnitude of rye effect, percentage reduction in mean seedling count (SCR\%) and percentage reduction in total dry weight (DWT\%) for the genotypes under both growing environments were estimated for the year 2015 data (Table 1 and Table 2 ). Percentage weed cover in each plot was visually estimated and the weed species were identified and recorded (Table 3 ).

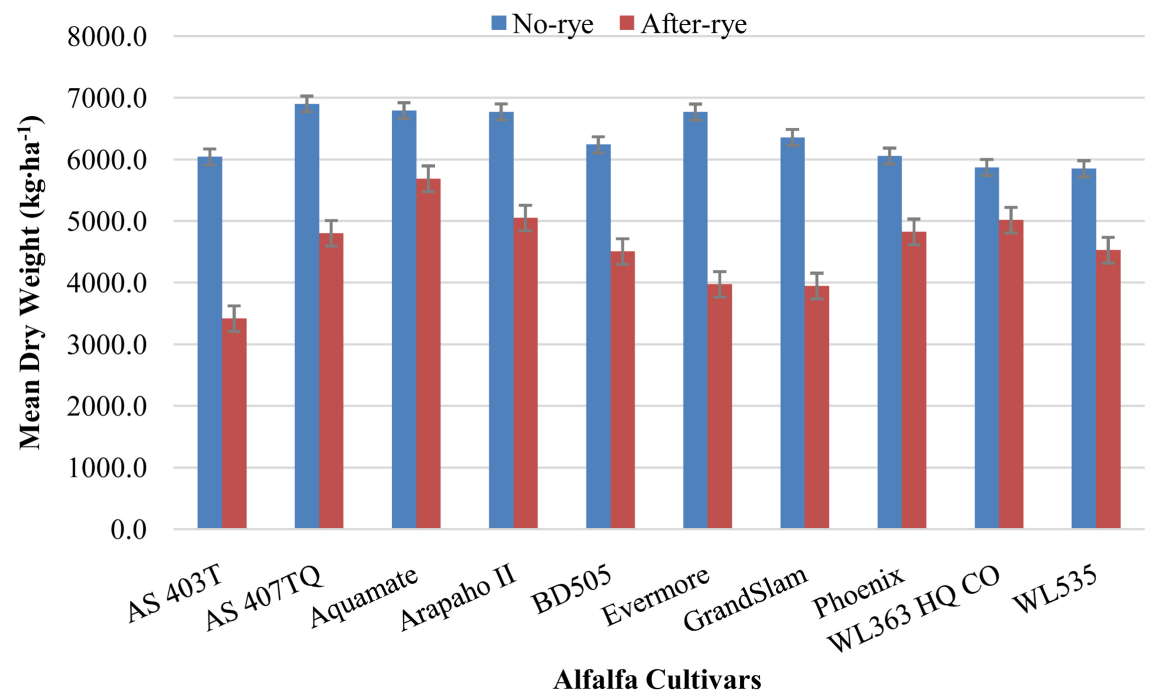

Figure 2. Mean total dry weight (DWT), over three harvests in 2015, of ten alfalfa cultivars planted following cereal rye as a previous crop (after-rye) and following no-rye. The plots were planted in April 2015 in Watkinsville, Georgia. Standard error bars are shown.

Table 1. Mean seedling count, and plant height of ten alfalfa cultivars grown after-rye and the same cultivars grown with no-rye in 2015. Seedlings count reduction percentage expresses the difference in seedlings count between the two environments.

\begin{tabular}{ccccccc}
\hline \multirow{2}{*}{ Genotypes } & \multicolumn{2}{c}{ Seedlings count $(\mathrm{SC})$} & & \multicolumn{2}{c}{ Plant height $(\mathrm{cm})$} \\
\cline { 2 - 3 } & no-rye & after-rye & & & no-rye & after-rye \\
\hline AS 403T & $21.8 \mathrm{c}$ & $7.9 \mathrm{~b}$ & 64 & 25.3 & 19.4 \\
AS 407TQ & $36.8 \mathrm{ab}$ & $17.5 \mathrm{ab}$ & 52 & 24.3 & 21.8 \\
Aquamate & $39.3 \mathrm{a}$ & $21.9 \mathrm{a}$ & 44 & 25.8 & 22.0 \\
Arapaho II & $24.6 \mathrm{abc}$ & $15.1 \mathrm{ab}$ & 38 & 24.8 & 26.3 \\
BD505 & $20.5 \mathrm{c}$ & $12.1 \mathrm{ab}$ & 41 & 25.0 & 24.4 \\
Evermore & $23.8 \mathrm{bc}$ & $11.1 \mathrm{ab}$ & 53 & 24.5 & 22.8 \\
GrandSlam & $31.1 \mathrm{abc}$ & $16.4 \mathrm{ab}$ & & 47 & 25.6 & 25.1 \\
Phoenix & $29.8 \mathrm{abc}$ & $11.4 \mathrm{ab}$ & 62 & 24.1 & 21.6 \\
WL363 HQ CO & $24.8 \mathrm{abc}$ & $14.8 \mathrm{ab}$ & 40 & 24.5 & 22.0 \\
WL535 & $25.0 \mathrm{abc}$ & $16.3 \mathrm{ab}$ & 35 & 26.8 & 26.1 \\
Average & 27.7 & 14.4 & 47.6 & 25.0 & 23.1 \\
\hline
\end{tabular}

Seedling count (SC) is the number of alfalfa seedlings per square foot. SCR $\%=$ Percentage reduction in seedling count. Numbers with the same letter are not significantly different based on Tukey's post-hock test at $\alpha=0.05$. 
Table 2. Mean total dry weight (DWT), over three harvests in 2015, of ten alfalfa cultivars planted after-rye and nor-rye and percentage reduction (DWTR\%) in total dry weight of the same cultivars between the two environments. The plots were planted in April 2015 in Watkinsville, Georgia.

\begin{tabular}{cccc}
\hline \multirow{2}{*}{ Genotypes } & \multicolumn{3}{c}{ Mean Total Dry Weight $(\mathrm{DWT})\left(\mathrm{kg} \cdot \mathrm{ha}^{-1}\right)$} \\
\cline { 2 - 4 } & no-rye & after-rye & DWTR\% \\
\hline AS 403T & $6042.5 \mathrm{a}$ & $3418.3 \mathrm{~b}$ & 43 \\
AS 407TQ & $6901.6 \mathrm{a}$ & $4801.7 \mathrm{ab}$ & 30 \\
Aquamate & $6793.9 \mathrm{a}$ & $5689.4 \mathrm{ab}$ & 16 \\
Arapaho II & $6772.4 \mathrm{a}$ & $5052.9 \mathrm{a}$ & 25 \\
BD505 & $6241.0 \mathrm{a}$ & $4507.2 \mathrm{ab}$ & 28 \\
Evermore & $6770.3 \mathrm{a}$ & $3975.1 \mathrm{ab}$ & 41 \\
GrandSlam & $6357.5 \mathrm{a}$ & $3948.3 \mathrm{ab}$ & 38 \\
Phoenix & $6056.5 \mathrm{a}$ & $4827.4 \mathrm{ab}$ & 20 \\
WL363 HQ CO & $5870.6 \mathrm{a}$ & $5016.8 \mathrm{ab}$ & 15 \\
WL535 & $5851.4 \mathrm{a}$ & $4527.8 \mathrm{ab}$ & 23 \\
Average & 6365.8 & 4576.5 & 27.9 \\
\hline
\end{tabular}

DWTR\% $=$ Percentage reduction in total dry weight. Numbers with the same letter are not significantly different based on Tukey's post-hock test at $\alpha=0.05$.

Table 3. Average weed cover percentage in ten alfalfa cultivars grown after-rye and no-rye in 2015, and the weed species found in each plots under the two environments.

\begin{tabular}{ccccc}
\hline \multirow{2}{*}{ Genotypes } & \multicolumn{2}{c}{ Weed cover (\%) } & \multicolumn{2}{c}{ Weed species } \\
\cline { 2 - 5 } & no-rye & after-rye & no-rye & after-rye \\
\hline AS 403T & 80.0 & 5 & Tp Ps Jg Cd Cg Ns Lq & Cg Tp Ps Rg \\
AS 407TQ & 73.3 & 5 & Cg Ps Tp Ns Mg & Cg Tp Ps \\
Aquamate & 86.7 & 5 & Cg Tp Rg Lq Ps Ns Jg & Cg Ps Jg Rg Pw \\
Arapaho II & 86.7 & 5 & Cg Tp Ps Rg Lq Ns Mg & Cg Ps Jg Lq Pw \\
BD505 & 66.7 & 5 & Cg Tp Ps Pw Rg Lq Ns Mg & Cg Ps \\
Evermore & 90.0 & 5 & Cg Ps Rg Pw Ns Mg Lq & Cg Tp Ps Jg \\
GrandSlam & 73.3 & 5 & Cg Tp Ps Lq Ns Rg & Cg Tp Ps Rg \\
Phoenix & 56.7 & 5 & Cg Tp Ps Pw Ns & Cg Tp Ps Jg \\
WL363 HQ CO & 83.3 & 5 & Cg Tp Rg Pw Ps Ns Mg & Cg Tp Ps Jg \\
WL535 & 76.7 & 5 & Cg Tp Ps Pw Ns Lq & Cg Tp Ps Jg \\
Average & 77.3 & 5 & & \\
\hline
\end{tabular}

Correlation between stand counts and dry weight biomass for the year of establishment was estimated using Pearson's correlation coefficient.

\section{Results and Discussions}

\subsection{Seedling Emergence and Establishment}

Seedling counts (SC) were significantly different $(\mathrm{p}<0.01)$ between the no-rye and after-rye treatments in 2015 (Table 1). The cultivar Aquamate had the 
highest mean SC (39.3) under no-rye condition, followed by AS 407TQ (36.8) and GrandSlam (31.1). The cultivar Aquamate had the highest mean SC (21.9) in the after-rye block, followed by AS 407TQ (17.5) and GrandSlam (16.4). In control (no-rye) block, the cultivar BD505 had the lowest number of mean SC (20.5) followed by AS 403T (21.8) and Evermore (23.8). Similarly, under the after-rye condition, the cultivar AS 403T had the lowest number of mean SC (7.9) followed by Evermore (11.1), Phoenix (11.4) and BD505 (12.2). The cultivar Phoenix is the only exception that had a higher number of SC under no-rye (29.8) and had relatively lower number of SC in the after-rye condition (Table 1). Seedling counts of the cultivars under both growing conditions was strongly correlated to each other $(r=-0.60, p<0.01)$. The mean SC over all the genotypes under no-rye was nearly twice that in the after-rye block (27.7 and 14.4, respectively). This implies that seed germination and seedling emergence of all the alfalfa genotypes were affected by rye allelopathy.

Under normal conditions of seed germination and no allelopathy, seedling count reduction percentage (SCR\%) between the same cultivars can be expected to be near $0 \%$. A large SCR \% indicates a strong allelopathic effect on the germination. The cultivar AS 403T exhibited the largest SCR (64\%) followed by Phoenix (62\%), Evermore (53\%), and AS 407TQ (52\%) (Table 1). Six cultivars showed less than 50\% of SCR including WL535, Arapaho II, WL363 HQ CO, BD505, Aquamate and GrandSlam and could have categorized as somewhat tolerant to rye allelopathy for seed germination and seedling emergence (Table 1). This is an indication that there might be genetic variation in the response to rye allelopathy between the alfalfa genotypes. Alfalfa cultivars with more than $50 \%$ reduction in stand count (SCR) can be considered more susceptible to cereal rye allelopathy.

\subsection{Plant Height and Yield}

Analysis of variance of plant heights collected from the after-rye and no-rye alfalfa plots did not show statistically significant differences at $\alpha=0.05$ (Table 1). Moreover, Tukey's post-hoc pairwise comparison also showed that there were no significant height differences between genotypes within the same treatment condition. However, the average plant heights across the two conditions were slightly different with mean height of $25.0 \mathrm{~cm}$ for plants under no-rye and 23.1 $\mathrm{cm}$ for plants grown after-rye (Table 1). The cultivar Araphao II exhibited a greater mean height in the after-rye plots $(26.3 \mathrm{~cm})$ than under no-rye condition (24.8). The cultivar AS 403T had the least plant height of $19.4 \mathrm{~cm}$ and the cultivar Arapaho II was the tallest $(26.3 \mathrm{~cm}$ ) in the after-rye plots (Table 1). These results indicate that alfalfa plant height may not be a major indicator to distinguish allelopathic effect of cereal rye between cultivars.

The impact of cereal rye on alfalfa seedling establishment clearly translated into low forage yield. The seedling counts and dry weight total were positively correlated to each other $(r=0.65, p<0.01)$, for the establishment year. Average 
total dry biomass weights (DWT) from all harvests (Figure 2, Table 2) was significantly different $(\mathrm{p}<0.01)$ between the same genotypes grown after-rye and no-rye conditions. Within the no-rye block, there were no significant differences $(\mathrm{p}>0.05)$ in DWT between the ten alfalfa cultivars, whereas in the after-rye treatment, there were differences in DWT of the ten cultivars, which may suggest that there is variability between the ten genotypes in their response to the allelopathic effect of rye. The mean dry weight over the 10 cultivars under no-rye was $6365.8 \mathrm{~kg} / \mathrm{ha}$, whereas the mean DWT was only $4576.5 \mathrm{~kg} / \mathrm{ha}$ in the after-rye plots. Under the no-rye condition, the cultivars AS 407, Aquamate, Araphol II, and Evermore displayed higher biomass dry weights whereas the cultivars WL535, WL363 HQ CO, and AS 403 showed lower dry weights even though the differences were not statistically significant (Figure 2, Table 2). In the after-rye condition, the cultivars Aquamate, Araphao II and WL363 HQ CO had higher dry biomass, while the cultivars AS 403T, GrandSlam, Evermore had lower biomass (Figure 2, Table 2). Over all the cultivars, there was an average reduction of $27.9 \%$ dry weight biomass yield in the after-rye condition compared to the no-rye. The reduction in DWRT\% was lower in WL363 HQ CO (15\%), Aquamate (16\%), and Phoenix (20\%). Similarly, higher reductions in dry biomass was observed in AS 403T (43\%) and Evermore (41\%) (Figure 2, Table 2). Thus, among the ten cultivars tested, Aquamate and WL363 HQ CO appear to have an acceptable tolerance to rye allelopathy since they showed the least reduction in dry weight biomass when grown after rye. Furthermore, we could not perceive noticeable differences related to the fall dormancy (FD) levels and the yield response to allelopathic effects for rye.

\subsection{Rye Effect on Weed Suppression in Alfalfa Plots}

Several studies indicated that weed control through allelopathy could be an environmentally friendly strategy and alternative to commercial herbicides that have several negative impacts [45]. However, effectiveness of use of rye allelopathy in controlling weeds in alfalfa stands had not been documented. This study investigated the potential use of rye allelopathy to control weeds in alfalfa. Although established stands of alfalfa are fairly competitive with weeds [46], seedlings are particularly susceptible to weed competition. Weeds emerging soon after seeding could reduce alfalfa stand establishment and eventually yield [47]. Managing weeds in a timely manner after alfalfa germination is necessary to prevent stand decline resulting in a reduction in forage yield and quality [48]. The presence of weeds in the alfalfa plots with no-rye was much greater than in the plots after-rye (Figure 1, Table 3 ). Average weed cover over the ten cultivars in the plots with no-rye was $77 \%$, while in the after-rye plots it was below $5 \%$ with variation between cultivars. The weed cover in the plots with no-rye varied from $56.7 \%$ in the cultivar Phoenix to $90 \%$ in plots with the cultivar Evermore (Table 3). Types of weeds also varied among the plots, however, there was no unique pattern of particular weed species to any specific cultivar (Table 3 ). Plots 
with the cultivar AS 407TQ had the least number of weed species (2.6) followed by AS $403 \mathrm{~T}$ and GrandSlam, whereas the cultivar WL363 HQ CO had the highest number of weed species (4.2) (Table 3). Major weeds found in this experiment were grass species (Table 3). Average numbers of weed species present in no-rye plots (4) were greater than the average number of species present in the after-rye blocks (3). These results clearly suggest the strong effect of rye in suppressing weeds in alfalfa plots, which is in agreement with the past reports on rye allelopathy on other crops for weed reduction [12]. It has been reported that rye can have allelopathic effects that reduce weed invasion by $80 \%$ [49] [50]. Barnes and Putnam (1986) also reported that spring planted rye reduced the biomass of common lambsquarters and common ragweed (Ambrosia artemissifolia L.) by more than $90 \%$ [51]. Rye was also effective in reducing large crabgrass weed by $42 \%$ and suppressing emergence of redroot pigweed and common purslane (Portulaca oleracea) by more than $90 \%$ [49] [51].

\subsection{Long-Term Effect of Rye Allelopathy on Alfalfa Yield}

In order to evaluate the long-term effects of rye allelopathy on alfalfa, we measured the total dry biomass production in 2017 (third year after establishment) under a four harvest system. Means of total dry biomass weight (DWT) across the 10 genotypes in the after-rye and no-rye groups showed no statistically significant differences $(\mathrm{p}>0.05)$ (Figure 3, Table 4). There was significant differences between the cultivars in total dry weight biomass $(\mathrm{p}<0.05)$ for the no-rye group but no difference $(\mathrm{p}>0.05)$ between the same cultivars in the after-rye treatment (Table 4). In the after-rye block, the cultivar WL363 HQ CO had the highest mean DWT of $16,411 \mathrm{~kg} / \mathrm{ha}$ followed by GrandSlam with $15,969 \mathrm{~kg} / \mathrm{ha}$

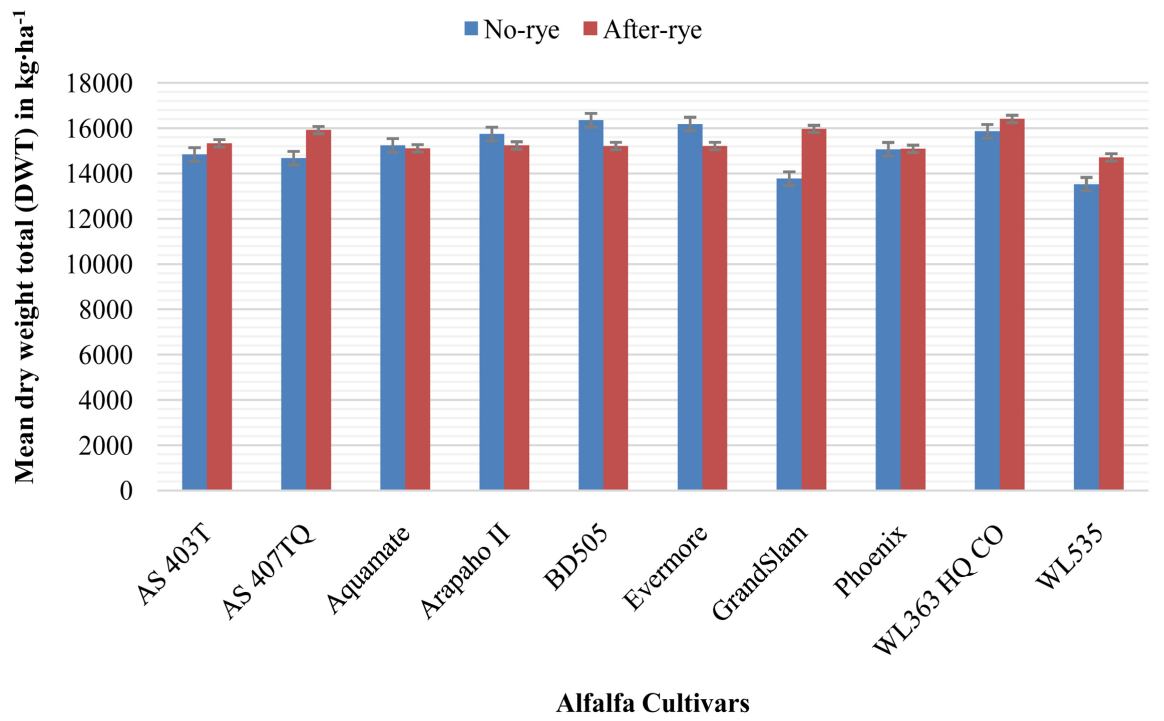

Figure 3. Mean total dry weight (DWT), over four harvests in 2017, of ten alfalfa cultivars planted following cereal rye as a previous crop (after-rye) and following no-rye. The plots were planted in April 2015 in Watkinsville, Georgia. Standard errors are shown on the top of each bar. 
Table 4. Mean total dry weight (DWT) over four harvests in 2017 of ten alfalfa cultivars planted after-rye and nor-rye, and percentage change in total dry weight between the same cultivar in the environments. The plots were established in April 2015. The arrows indicate whether the change is an increase or a decrease.

\begin{tabular}{|c|c|c|c|}
\hline \multirow[t]{2}{*}{ Genotypes } & \multicolumn{2}{|c|}{ 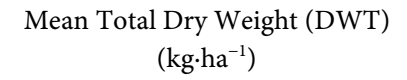 } & \multirow[t]{2}{*}{$\%$ change in DWT } \\
\hline & no-rye & after-rye & \\
\hline AS $403 \mathrm{~T}$ & $14,841.6 \mathrm{abc}$ & $15,334.4 \mathrm{a}$ & 3.3 \\
\hline AS 407TQ & $14,681.4 \mathrm{abc}$ & $15,919.1 \mathrm{a}$ & 8.4 \\
\hline Aquamate & $15,237.8 \mathrm{abc}$ & $15,110.9 \mathrm{a}$ & 0.8 \\
\hline Arapaho II & $15,743.7 \mathrm{abc}$ & $15,239.2 \mathrm{a}$ & 3.2 \\
\hline BD505 & $16,357.7 \mathrm{a}$ & $15,217.0 \mathrm{a}$ & 7.0 \\
\hline Evermore & $16,182.0 \mathrm{a}$ & $15,218.7 \mathrm{a}$ & 6.0 \\
\hline GrandSlam & $13,776.7 \mathrm{bc}$ & $15,969.2 \mathrm{a}$ & 15.9 \\
\hline Phoenix & $15,069.9 \mathrm{abc}$ & $15,089.8 \mathrm{a}$ & 0.1 \\
\hline WL363 HQ CO & $15,860.4 \mathrm{ab}$ & $16,411.1 \mathrm{a}$ & 3.5 \\
\hline WL535 & $13,526.9 \mathrm{c}$ & $14,713.7 \mathrm{a}$ & 8.8 \\
\hline Average & $15,127.8$ & $15,422.3$ & 2.3 \\
\hline
\end{tabular}

Numbers with the same letter are not significantly different based on Tukey's post-hock test at $\alpha=0.05$.

(Figure 3). The cultivar WL535 had the lowest total DWT of $14,714 \mathrm{~kg} / \mathrm{ha}$ followed by the cultivar Phoenix with 15,090 kg/ha (Figure 3, Table 4). Among the cultivars in the no-rye block, BD505 produced the highest DWT of $16,358 \mathrm{~kg} / \mathrm{ha}$ followed by Evermore with $16,182.0 \mathrm{~kg} / \mathrm{ha}$. The cultivar WL535 had the lowest forage yield with 13,527 kg/ha followed by GrandSlam with 13,777 kg/ha (Figure 3, Table 4). The variation in biomass dry weights among the alfalfa cultivars within the no-rye and the after-rye blocks could be related to the variation in stand persistence and performance differences between cultivars in the particular testing environment. Out of the ten cultivars, six showed more DWT in the after-rye condition than the no-rye, and four showed more DWT in no-rye condition than the after-rye condition (Figure 3, Table 4). The change in the magnitude of differences in DWT between the same genotypes grown after-rye and no-rye blocks in 2017 compared to that of the establishment year (2015) might have been the result of the historical drought of the year 2016. The year 2016 was one of the driest years on record in Georgia. The J. Phil Campbell site received 32.3 inches of rain, which was half of 2015 ( 62 inches). The numbers of rainy days were only 94 compared to 142 days in 2015 and about 139 days in 2013. Only 11.2 inches were recorded from the end of May to September. This has most likely resulted in stand kill of the densely populated plots in the no-rye compared to the after-rye plots that were very thin and therefore did not suffer much from the drought. The sparsely spaced plants in the after rye plots, had more room to spread, which might have favored the generation of more tillers. The presence of weeds in the 2017 was not different between the after-rye and no-rye blocks, suggesting that the effect of rye allelochemicals in the soil may not 
persist beyond the first season after planting. These results corroborate reports that indicated that allelopathy could remain in the soil from a few to several weeks, but definitely has limited persistence because the allelochemicals are degradable [52]. Allelochemical compounds from rye, such as benzoxazinoids, produce phenoxazinones that degraded by Fenton reaction in presence of a fungi [25].

The variable responses displayed by the alfalfa cultivars tested in this study following rye as a previous crop could be an indication that there might be genetic variation among these alfalfa cultivars as to their response to rye allelopathy. For instance, the cultivars Aquamate and WL363 HQ CO were least affected and might harbor some biochemical mechanism allowing them to overcome the effect of allelopathy. The genetic mechanism involved in alfalfa to response to rye allelopathy is mostly unknown. However, the results of this study point to the existence of genetic variation that could be exploited for breeding alfalfa cultivars with high tolerance to rye allelopathy and consequently capitalize on the biological weed control potential of rye.

\section{Conclusion}

The results of the present study clearly show that cereal rye suppresses weeds and reduces their establishment by up to $77 \%$ in the succeeding alfalfa crop. At the same time, the allelopathic effect of cereal rye on alfalfa leads to reduction in seedling emergence by up to $64 \%$, stand establishment, and eventually forage yield. These observations suggest that the allelopathic effect of rye on alfalfa may not persist beyond the establishment season, but the enormous yield reduction $(15 \%-43 \%)$ in the first production year may constitute a costly economic penalty in terms of forage production. Therefore, growing cereal rye as a cover crop preceding alfalfa may need to be considered carefully, given the enormous reduction in stand establishment and forage yield. There was variation in the response of different alfalfa cultivars to the effect of rye residue as indicated by the magnitude of reduction in stand count and forage yield. This warrants more research in multi-location trials with and without rye in order to establish whether there is genetic variation in alfalfa germplasm in their tolerance to cereal rye allelopathy. Weed control in alfalfa using rye allelopathy would be effective if alfalfa cultivars tolerant to rye allelopathy are developed. Future research may also need to focus on applying analytical chemistry to understand the nature of allelochemicals present in rye and their mechanism of action on alfalfa.

\section{Acknowledgements}

The authors acknowledge the research associate Jonathan D. Markham and former lab technician Joseph Young for their assistance to accomplish the project.

\section{References}

[1] Adhikari, L. and Missaoui, A.M. (2017) Nodulation Response to Molybdenum Supplementation in Alfalfa and It's Correlation with Root and Shoot Growh in Low Ph 
Soil. Journal of Plant Nutrition, 40, 2290-2302.

https://doi.org/10.1080/01904167.2016.1264601

[2] http://usda.mannlib.cornell.edu/usda/current/Acre/Acre-06-30-2017.pdf

[3] Li, X. and Brummer, E.C. (2012) Applied Genetics and Genomics in Alfalfa Breeding. Agronomy, 2, 40. https://doi.org/10.3390/agronomy2010040

[4] Wolfe, E. and Southwood, O. (1980) Plant Productivity and Persistence in Mixed Pastures Containing Lucerne at a Range of Densities with Subterranean Clover or Phalaris. Australian Journal of Experimental Agriculture, 20, 189-196. https://doi.org/10.1071/EA9800189

[5] Fischer, A.J., Dawson, J.H. and Appleby, A.P. (1988) Interference of Annual Weeds in Seedling Alfalfa (Medicago sativa). Weed Science, 36, 583-588.

[6] Cords, H. (1973) Weeds and Alfalfa Hay Quality. Weed Science, 21, 400-401.

[7] Dowdy, K., Berberet, R., Stritzke, J., Caddel, J. and McNew, R. (1993) Interaction of Alfalfa Weevil (Coleoptera: Curculionidae), Weeds, and Fall Harvest Options as Determinants of Alfalfa Productivity. Journal of Economic Entomology, 86, 1241-1249. https://doi.org/10.1093/jee/86.4.1241

[8] Hoveland, C., Durham, R. and Bouton, J. (1996) Weed Encroachment in Established Alfalfa as Affected by Cutting Frequency. Journal of Production Agriculture, 9, 399-402. https://doi.org/10.2134/jpa1996.0399

[9] Norris, R.F. and Ayres, D. (1991) Cutting Interval and Irrigation Timing in Alfalfa: Yellow Foxtail Invasion and Economic Analysis. Agronomy Journal, 83, 552-558. https://doi.org/10.2134/agronj1991.00021962008300030007x

[10] Moyer, J., Fraser, J., Rode, L. and Topinka, A. (1999) Effects of Growth-Stage-Based Alfalfa Harvest on Weed Encroachment and Resultant Quality. Canadian Journal of Plant Science, 79, 243-247. https://doi.org/10.4141/P98-059

[11] Haby, V.A., Davis, J.V. and Leonard, A.T. (1999) Response of Overseeded Alfalfa and Bermudagrass to Alfalfa Row Spacing and Nitrogen Rate. Agronomy Journal, 91, 902-910. https://doi.org/10.2134/agronj1999.916902x

[12] Barnes, J.P. and Putnam, A.R. (1983) Rye Residues Contribute Weed Suppression in No-Tillage Cropping Systems. Journal of Chemical Ecology, 9, 1045-1057. https://doi.org/10.1007/BF00982210

[13] Moore, M.J., Gillespie, T.J. and Swanton, C.J. (1994) Effect of Cover Crop Mulches on Weed Emergence, Weed Biomass, and Soybean (Glycine max) Development. Weed Technology, 8, 512-518.

[14] Raimbault, B., Vyn, T. and Tollenaar, M. (1990) Corn Response to Rye Cover Crop Management and Spring Tillage Systems. Agronomy Journal, 82, 1088-1093. https://doi.org/10.2134/agronj1990.00021962008200060012x

[15] Putnam, A.R., Defrank, J. and Barnes, J.P. (1983) Exploitation of Allelopathy for Weed Control in Annual and Perennial Cropping Systems. Journal of Chemical Ecology, 9, 1001-1010. https://doi.org/10.1007/BF00982207

[16] Barnes, J.P. and Putnam, A.R. (1987) Role of Benzoxazinones in Allelopathy by Rye (Secale cereale L.). Journal of Chemical Ecology, 13, 889-906. https://doi.org/10.1007/BF01020168

[17] Jabran, K. (2017) Rye Allelopathy for Weed Control. Manipulation of Allelopathic Crops for Weed Control. Springer International Publishing, Cham, 49-56. https://doi.org/10.1007/978-3-319-53186-1_6

[18] Barnes, J.P. and Putnam, A.R. (1986) Evidence for Allelopathy by Residues and Aqueous Extracts of Rye (Secale cereale). Weed Science, 34, 384-390. 
[19] Raimbult, B.A., Vyn, T.J. and Tollenaar, M. (1991) Corn Response to Rye Cover Crop, Tillage Methods, and Planter Options. Agronomy Journal, 83, 287-290. https://doi.org/10.2134/agronj1991.00021962008300020005x

[20] Pérez, F. and Ormeno-Núnez, J. (1993) Weed Growth Interference from Temperate Cereals: The Effect of a Hydroxamic-Acids-Exuding Rye (Secale cereale L.) Cultivar Weed Research, 33, 115-119. https://doi.org/10.1111/j.1365-3180.1993.tb01924.x

[21] Pérez, F.J. and Ormenoñuñez, J. (1991) Difference in Hydroxamic Acid Content in Roots and Root Exudates of Wheat (Triticum aestivum L.) and Rye (Secale cereale L.): Possible Role in Allelopathy. Journal of Chemical Ecology, 17, 1037-1043. https://doi.org/10.1007/BF01402932

[22] Xuan, T.D. and Tsuzuki, E. (2002) Varietal Differences in Allelopathic Potential of Alfalfa. Journal of Agronomy and Crop Science, 188, 2-7. https://doi.org/10.1046/j.1439-037x.2002.00515.x

[23] Hicks, S.K., Wendt, C.W., Gannaway, J.R. and Baker, R.B. (1989) Allelopathic Effects of Wheat Straw on Cotton Germination, Emergence, and Yield. Crop Science, 29, 1057-1061. https://doi.org/10.2135/cropsci1989.0011183X002900040048x

[24] Khanh, T., Chung, M., Xuan, T. and Tawata, S. (2005) The Exploitation of Crop Allelopathy in Sustainable Agricultural Production. Journal of Agronomy and Crop Science, 191, 172-184. https://doi.org/10.1111/j.1439-037X.2005.00172.x

[25] Cheng, F. and Cheng, Z. (2015) Research Progress on the Use of Plant Allelopathy in Agriculture and the Physiological and Ecological Mechanisms of Allelopathy. Frontiers in Plant Science, 6, 1-16. https://doi.org/10.3389/fpls.2015.01020

[26] Bhowmik, P.C. and Inderjit (2003) Challenges and Opportunities in Implementing Allelopathy for Natural Weed Management. Crop Protection, 22, 661-671. https://doi.org/10.1016/S0261-2194(02)00242-9

[27] Kruse, M., Strandberg, M. and Strandberg, B. (2000) Ecological Effects of Allelopathic Plants-A Review. NERI Technical Report No. 315, National Environmental Research Institute, Silkeborg.

[28] Suman, A., Shahi, H.N., Singh, P. and Gaur, A. (2002) Allelopathic Influence of Vigna mungo (Black Gram) Seeds on Germination and Radical Growth of Some Crop Plants. Plant Growth Regulation, 38, 69-74. https://doi.org/10.1023/A:1020943011207

[29] Mondal, M.F., Asaduzzaman, M. and Asao, T. (2015) Adverse Effects of Allelopathy from Legume Crops and Its Possible Avoidance. American Journal of Plant Sciences, 6, 804-810. https://doi.org/10.4236/ajps.2015.66086

[30] Macias, F.A. (1995) Allelopathy in the Search for Natural Herbicide Models. ACS Symposium Series, 582, 310-329

[31] Forney, D.R. and Foy, C.L. (1985) Phytotoxicity of Products from Rhizospheres of a Sorghum-Sudangrass Hybrid (Sorghum bicolor X Sorghum sudanense). Weed Science, 33, 597-604.

[32] Xuan, T.D., Tsuzuki, E., Terao, H., Matsuo, M., Khanh, T.D., Murayama, S., et al. (2003) Alfalfa, Rice by-Products and Their Incorporation for Weed Control in Rice. Weed Biology and Management, 3, 137-144. https://doi.org/10.1046/j.1445-6664.2003.00095.x

[33] Xuan, T.D., Tsuzuki, E., Uematsu, H. and Terao, H. (2001) Weed Control with Alfalfa Pellets in Transplanting Rice. Weed Biology and Management, 1, 231-235. https://doi.org/10.1046/j.1445-6664.2001.00034.x

[34] Abdul-Rahman, A.A. and Habib, S.A. (1989) Allelopathic Effect of Alfalfa (Medi- 
cago sativa) on Bladygrass (Imperata cylindrica). Journal of Chemical Ecology, 15, 2289-300. https://doi.org/10.1007/BF01012082

[35] Olofsdotter, M. (2001) Rice-A Step toward Use of Allelopathy. Agronomy Journal, 93, 3-8. https://doi.org/10.2134/agronj2001.9313

[36] Gealy, D.R. and Yan, W. (2012) Weed Suppression Potential of "Rondo" and Other Indica Rice Germplasm Lines. Weed Technology, 26, 517-524. https://doi.org/10.1614/WT-D-11-00141.1

[37] Wu, H., Pratley, J., Ma, W. and Haig, T. (2003) Quantitative Trait Loci and Molecular Markers Associated with Wheat Allelopathy. Theoretical and Applied Genetics, 107, 1477-1481. https://doi.org/10.1007/s00122-003-1394-x

[38] Głąb, L., Sowiński, J., Bough, R. and Dayan, F.E. (2017) Chapter Two-Allelopathic Potential of Sorghum (Sorghum bicolor (L.) Moench) in Weed Control: A Comprehensive Review. In: Sparks, D.L., Ed., Advances in Agronomy, Academic Press, 43-95.

[39] Reberg-Horton, S.C., Burton, J.D., Danehower, D.A., Ma, G., Monks, D.W., Murphy, J.P., et al. (2005) Changes over Time in the Allelochemical Content of Ten Cultivars of Rye (Secale cereale L.). Journal of Chemical Ecology, 31, 179-193. https://doi.org/10.1007/s10886-005-0983-3

[40] Bezuidenhout, S., Reinhardt, C. and Whitwell, M. (2012) Cover Crops of Oats, Stooling Rye and Three Annual Ryegrass Cultivars Influence Maize and Cyperus esculentus Growth. Weed research, 52, 153-160. https://doi.org/10.1111/j.1365-3180.2011.00900.x

[41] Tabaglio, V., Marocco, A. and Schulz, M. (2013) Allelopathic Cover Crop of Rye for Integrated Weed Control in Sustainable Agroecosystems. Italian Journal of Agronomy, 8, 5. https://doi.org/10.4081/ija.2013.e5

[42] Brooks, A.M., Danehower, D.A., Murphy, J.P., Reberg-Horton, S.C. and Burton, J.D. (2012) Estimation of Heritability of Benzoxazinoid Production in Rye (Secale cereale) Using Gas Chromatographic Analysis. Plant Breeding, 131, 104-109. https://doi.org/10.1111/j.1439-0523.2011.01885.x

[43] Climate Watkinsville-Georgia. https://www.usclimatedata.com/climate/watkinsville/georgia/united-states/usga1729

[44] Nordt, C., Rössler, W. and Lauber, C. (2006) Attitudes of Mental Health Professionals toward People with Schizophrenia and Major Depression. Schizophrenia Bulletin, 32, 709-714. https://doi.org/10.1093/schbul/sbj065

[45] Macías, F.A., Molinillo, J.M., Varela, R.M. and Galindo, J.C. (2007) Allelopathy-A Natural Alternative for Weed Control. Pest Management Science, 63, 327-348. https://doi.org/10.1002/ps.1342

[46] Dillehay, B.L., Curran, W.S. and Mortensen, D.A. (2011) Critical Period for Weed Control in Alfalfa. Weed Science, 59, 68-75. https://doi.org/10.1614/WS-D-10-00073.1

[47] Zimdahl, R. (2004) The Effect of Competition Duration. Weedcrop Competition: A Review. 2nd Edition, Blackwell Publishing, Ames, IA, 109-130. https://doi.org/10.1002/9780470290224.ch6

[48] Wilson, R.G. (1997) Downy Brome (Bromus tectorum) Control in Established Alfalfa (Medicago sativa). Weed technology, 11, 277-282.

[49] Putnam, A.R. and DeFrank, J. (1983) Use of Phytotoxic Plant Residues for Selective Weed Control. Crop Protection, 2, 173-181.

https://doi.org/10.1016/0261-2194(83)90042-X 
[50] Ngouajio, M. and Mennan, H. (2005) Weed Populations and Pickling Cucumber (Cucumis sativus) Yield under Summer and Winter Cover Crop Systems. Crop Protection, 4, 521-526. https://doi.org/10.1016/j.cropro.2004.10.004

[51] Barnes, J.P. and Putnam, A.R. (2017) Evidence for Allelopathy by Residues and Aqueous Extracts of Rye (Secale cereale). Weed Science, 34, 384-390.

[52] United States Department of Agriculture (2016) Allelopathy and Cover Crops. https://www.nrcs.usda.gov/Internet/FSE_PLANTMATERIALS/publications/mopm stn2825.pdf

\section{Abbreviations}

\begin{tabular}{cccc}
\hline Ameristand 403T & AS 403T & Morning glory (Convolvulaceae sp.) & $\mathrm{mg}$ \\
Ameristand 407TQ & AS 407TQ & Nutsedge (Cyperus sp.) & $\mathrm{ns}$ \\
Bermudagrass (Cynodon dactylon L.) & $\mathrm{bg}$ & Pigweed (Amaranthus retroflexus) & $\mathrm{pw}$ \\
Crabgrass (Digitaria sanguinalis L.) & $\mathrm{cg}$ & Prostrate spurge (Euphorbia maculate) & $\mathrm{ps}$ \\
Curly dock (Rumex crispus) & $\mathrm{cd}$ & Ryegrass (Lolium sp.) & $\mathrm{rg}$ \\
Iron weed (Veronia sp.) & $\mathrm{iw}$ & Sickle pod (Senna obtusifolia) & $\mathrm{sp}$ \\
Johnsongrass (Sorghum halepense) & $\mathrm{Jg}$ & Texas panicum (Panicum texanum) & $\mathrm{tp}$ \\
Lambsquarters & $\mathrm{lq}$ & Virgnia Pepperweed & $\mathrm{vp}$ \\
(Chenopodium album) & & (Lepidium virginicum L.) & $\mathrm{m}$
\end{tabular}

